\title{
'A selection of minor antiquities': a multi-sited view on collections from excavations in Egypt
}

Alice Stevenson, Emma Libonati and Alice Williams

\begin{abstract}
This paper draws upon the 'Artefacts of Excavation' (2014-2017) project, which is investigating the worldwide distribution of finds from British-led excavations in Egypt between 1880 and 1980. The departure point for the present article is the earliest phase of these distributions. The potential for multi-sited ethnographic approaches to illuminate the history and significance of such collections is explored. It is argued that through multi-sited analyses that it is possible to chart shifting tensions in the status of objects as they were collected, circulated and re-evaluated between the field and the museum. The paper concludes by suggesting that multi-sited frameworks may also be able to re-animate 'orphaned' archaeological collections, some of which could be at risk from commercial sale.
\end{abstract}

Keywords multi-sited ethnography, museum, Egyptian archaeology, history of collections

\section{Introduction}

Many of the earliest entries in the Egypt Exploration Fund (EEF) register of archaeological finds distributed to institutions worldwide are listed somewhat nonchalantly as 'a selection of minor antiquities' (Table 1). Acquired by Flinders Petrie's teams through excavation and purchase in the Delta, at sites such as Tanis (1883-84), Naukratis (1884-86) and Tell Dafana (1886), they included gaming pieces, pottery, pendants, little figurines, ring bezels, pieces of cut glass, rosettes, scraps of bronze-work and beads (e.g. Petrie 1885, 27-41). While perhaps individually incidental, collectively these trifles, oddments and trinkets - as they are variously referred to in EEF correspondence of the time-were potentially anything but.

In this paper we explore how the collecting of these more mundane relics became pivots around which the emergent discipline of archaeology was forged, how they became touchstones for debates about who owned the rights to the past, and where archaeological practice and knowledge was located and constructed. In doing so we aim to tease apart some of the truisms common in histories of archaeology that exalt field collecting practices such as Petrie's, as well as the emphasis upon the value of unassuming, quotidian things for archaeological inference. There is a 'presentism' (Trigger 1996, 26) to such homages and an assumption that the worth of these things was self-evident. But what in the late nineteenth century made such objects 'archaeological' in the first place? How, in an age where the public reception of antiquity had hitherto depended upon the exceptional quiddity of the artefact (Bohrer 2003, 2; Moser 2006), could accumulations of sherds, beads and small miscellaneous fragments become appreciated and accommodated within collections? These are ontological questions about categories of objects whose status in the politics of collecting was not necessarily essential or stable, but repeatedly constructed and deconstructed. 
An informative parallel for this argument can be found, as observed by William Carruthers $(2014,169)$, in the work of historian Gabrielle Hecht (2012), who has described how uranium's nuclear status, and thereby its mobility through various networks, was dependent upon its construction as either a banal commodity or something exceptional because of its status in the nuclear world. Similar tensions between the claims of banality and exceptionalism can be seen to play out in the acquisition of artefacts from the field in Egypt, their subsequent distribution, and their eventual incorporation into institutional collections. Such frictions, which continued throughout the course of a century, reveal the complexities of collecting practices which assembled and reassembled excavated finds. This article considers a number of different locations in the distribution network: the archaeological dig in Egypt, the Service du Antiquités de l'Égypte in Cairo, temporary exhibitions in London, EEF committee meetings, international museums and the modern-day auction house. Although the relationships between these sites cannot be examined comprehensively in the space available here, we hope to at least introduce the potential of multi-sited ethnographic approaches to understanding and advocating the value and significance of collections. The aim is not to simply chronicle developments in the history of archaeological collections, but to examine some of the social, political, economic and intellectual contexts that shaped them and which continue to affect them today.

\section{A multi-sited project}

Previous accounts of finds 'partage' have largely been focused on a single site, either narrating specific institutional histories (e.g. Bagh 2011) or reconstructing particular excavations or sites (e.g. Robson et al. 2014; Leclère and Spencer 2014; Franzmeier 2014). By taking a more holistic approach to the practice, a much denser picture of the historical underpinnings of the division and dispersal of excavated material emerges. This is especially apparent when confronting the daunting archival legacy that accumulated in the midst of negotiations for discoveries. In addressing such intricacies this study benefits from several decades of scholarship that has emerged from conceptions of object biographies (Appadurai 1986; Gosden and Marshall 1999), which emphasise the shifting value of artefacts throughout their life-courses. The concept, together with aspects of Actor-Network-Theory (ANT), has had particular currency in museum studies, where it has highlighted the manner in which museums operate within wide-ranging socio-material networks (Gosden and Knowles 2001; Alberti 2005; Bennett 2014), most notably in the model of the 'relational museum' (Gosden and Larson 2007). The 'Artefacts of Excavation' project, which is funded by the UK's Arts and Heritage Research Council (AHRC), is similarly informed by enquiries into the relational links between the field and the museum, which are contingent upon constantly fluctuating social, political, economic and intellectual conditions (Livingstone 2003; Hill 2006; Bennett 2014).

In view of these theoretical concerns - which reaffirm how the significance of artefacts is dependent upon history and geography - this examination is inspired methodologically by multi-sited ethnographic approaches (Falzon 2009; Marcus 1995; Coleman and Hellerman 2011) that allow for 'the layering of partly incommensurable experiences in different places through time, and tracing the connections and disjunctions between them' (Candea 2013, 252). The multi-sited ethnography model is particularly germane to understanding the collection and distribution of finds in being 'designed around chains, paths, threads, conjunctions, or 
juxtapositions of locations' (Marcus 1995, 105). Not only does multi-sitedness extend the fieldsite geographically, it also accommodates temporal depth. The ethos of the multi-sited project additionally encapsulates far better than the relational museum model the nature of socio-material networks, approaches to which have been criticised for their linearity, neatness and flatness (Larson, Petch and Zeitlyn 2007, 217). The goal here is to present multiple contextualizations (Jenkins 1994, 244), focusing on relationships between different settings or, in a more dynamic sense 'regimes of value' (Appaudurai 1986), in which the archaeological object was emergent. Such 'regimes of value' were (and still are) infused with competing interests and motivations, from the popular to the scientific, from the general to the intellectual. The approach's multi-scalar sensitivities also valuably frame investigations that oscillate between global and local narratives. The current study relates, on the one hand, to imperial and colonial endeavours in Egypt, while on the other hand it interleaves more local concerns of institutional politics and personal relationships through which international conceptions of Egypt were localized.

Existing relational museum approaches to collections tend to be grounded in one specific museum collection, its objects and archives, examining how a museum draws into itself not only objects, but networks of people. A multi-sited ethnographic approach to collection histories is not so neat nor institutionally-bounded. Rather, it seeks to juxtapose and layer information from many locations and consider processes of knowledge production not just at the metropoles, but also along peripheries. It additionally takes account of the competing forces of several institutions between which collections were fragmented and reformulated. Among the challenges of such a multi-sited approach are how to achieve an appropriate scope and relevance of analysis amidst so many competing perspectives, and how to avoid producing shallow accounts of specific contexts of reception. More positively, however, this breadth can emerge as a strength, making it possible to confront dominant narratives and provide a corrective to over-generalizations that place all agency for archaeological collecting solely in the hands of field directors.

\section{Negotiating value in Egypt}

In the nineteenth century, the legal and political framework within which institutional control of Egyptian antiquities was exerted had had little impact on the European exploitation of excavations in Egypt (Colla 2007). Effectively, these laws continued to privilege western hegemony and placed Europeans as the caretakers of Egypt's past, Europeans who were in direct competition for cultural capital (e.g. Hoock 2007). In 1882 Britain forcibly occupied Egypt, installing its representatives in almost all areas of state governance. One exception was the Department of Egyptian Antiquities (Service des Antiquités de l'Égypte), which since its foundation had always been headed by a Frenchman (Reid 1997). Buffering any negotiations on rights to excavation and finds, therefore, were two different traditions of archaeology: French approaches, underpinned by centralised administration and government funding (Kohl and Fawcett 1995; Diaz-Andreu 2007), and British interests, driven by private, middle- and upper-class initiatives. The latter inflected a particular sort of tension in which British archaeology abroad had to gain not only scientific approval, but also more popular assent. As the Oxford Assyriologist A.H. Sayce warned in 1883: 
'Where the government is not enlightened enough to spend money upon excavations, the sensational has to be considered in the first place, the scientific only in the second.' (Sayce 1883)

The sensational was clearly a consideration when the establishment of the Egypt Exploration Fund (EEF) was announced in The Times on April 1 1882, since it did so with the enticing headline 'Egyptian Antiquities', implying that investment in excavations in Egypt would result in material rewards. Yet the final line of that article confessed that 'it must be distinctly understood that by the law of Egypt no antiquities can be removed from the country'. Nevertheless, through the EEF hundreds of thousands of objects were eventually exported and dispersed far beyond Egypt's borders. At first these were merely a few handfuls of things stuffed into Petrie's pockets (Drower 1985, 64), but rapidly that became voluminous crates of artefacts. By the 1896-97 season at El-Kab, some 54 boxes of pottery and sundries were delivered to museums around the world (Quibell 1898, 1). Between 1883 and 1915 the EEF distributed thousands of artefacts to more than 75 institutions in the UK, at least 35 destinations in the USA and a further 35 museums worldwide (Stevenson 2014). Between 1880 and 1980 we estimate that the excavation of around 109 sites through 266 discrete seasons resulted in almost 400 institutions globally receiving objects. Material from the EEF's two seasons at Naukratis alone, have ultimately been spread to more than 50 museums in five continents (Villing n.d.).

The very first spoils from the EEF's work comprised two granite sculptures from Edouard Naville's dig at Tell el-Maskhuta. These were a personal gift from the Khedive, Muhammed Tewfik Pasha, to Sir Erasmus Wilson, President of the EEF, through the intervention of the French director of the Service des Antiquités de l'Égypte, Gaston Maspero. They were duly sent to the British Museum, where they remain to this day (EA 1007/1883, 1107.2; EA 1006/1883, 1107.2). These statues constituted an exceptional political gift linked to the state (cf. Carruthers 2014, 169) that fit neatly into the heroically-styled collecting practices of previous decades, such as those of Charles Fellows in Lycia, Austen Henry Layard at Nineveh, and John Turtle Wood at the Temple of Artemis at Ephesus (Moser 2006; Challis 2008).

Petrie's more numerous but humbler offerings from his EEF-sponsored endeavours in the Delta during the following years constituted a stark contrast (Fig. 1). It was plausibly their very materiality - small, portable, multiple - that permitted them to circumvent legislative controls and the interests of the Services des Antiquités, which more readily identified the unique and colossal as subjects of control (Stevenson 2014). Yet the potential for such objects to transcend borders was not solely assessed upon their essential qualities, but was also depended upon institutional infrastructures, political situations, personal relationships and scientific knowledge. In order to be released from state control these objects had to first be actively constructed as something ordinary and unexceptional. In practice this meant that some material had to pass through a 'commodity phase' (Appadurai 1986) by which antiquities came to be governed by economic rather than political mechanisms.

The intricacy of the negotiations within this regime of value is evident from a series of missives between Flinders Petrie and Gaston Maspero today held in the Egypt Exploration Society's ${ }^{1}$ Lucy Gura archive (EES archive box XVI, f). The two men were on friendly terms that permitted discussions to transcend nationalistic biases and 
facilitated dialogues on the export of excavated artefacts in the 1880s. Together, they eventually came to an agreement that effectively paved the way for the officiallysanctioned exodus of Egyptian antiquities to foreign countries through a process that came to be known as 'partage', a model of imperial collecting later extended to the management of finds from excavations in countries such as Sudan, Iraq, Turkey, Palestine and Afghanistan (Kersal 2010).

In a letter to the EEF's Reginald Poole, dated 28 January 1883, Petrie outlined the new agreement. It stated that 'all objects of any nature, value or age, discovered in working' belonged to the Egyptian Government and must be deposited in the museum at Bulaq in Cairo. It went on to identify another class of material, which included objects purchased in the area of Petrie's archaeological concessions and which 'must be submitted to the administration with right of choice and purchase in reimbursement'. Petrie concluded that:

'From this you will see that the museum will not claim to take what I may deem requisite to buy in places apart from excavating; such things being left to the ordinary rules of exchange or otherwise. Also that the museum reimburses whatever I may pay for things found at the works and by act of paying for such things to the workmen, I take them out of the category of things belonging to the government, and leave them subject to the right of choice.' (Petrie 1883)

It is frequently presumed that material acquired via Petrie was a direct result of scientific excavation, but as is evident from correspondence such as this he had multiple modes of procurement. Contrary to received wisdom, Petrie's idea of context was not the one most archaeologists would consider today, which anchors objects to particular archaeological features, but one that gave objects historical significance in a more normative sense. Sometimes this was a specific grave, but in terms of purchase simply a generic reference to a significant geographical locale was sufficient for his purposes of attaching a date to an object. It is also clear from the above quote that an object's potential for acquisition depended upon a series of developing colonial relationships with the local Egyptian workforce who were responsible for not just careful excavation (Quirke 2010; Doyon 2015), but who additionally evaluated which objects would appeal to Petrie's collecting instincts and his purse. These relationships would come to shape the resulting assemblages sent back to London.

At the end of his first season excavating for the EEF Petrie wrote to Maspero identifying two categories of finds: 'things of value' and 'objects of no particular value but worth taking to England' (Petrie 1884). Maspero permitted these 'unexceptional objects' to leave Egypt and in so doing, he paved the way for a diaspora of excavated material to the world's museums that lasted for a century, the most intense period being between the 1880s and the 1920s, but continuing until Egypt enacted the 1983 Egyptian Law on the Protection of Antiquities.

\section{Negotiating value outside of Egypt}

Petrie's tactics had been successful in facilitating the export of objects, but on import into Britain these same artefacts, which had been constructed as mundane, unexceptional relics, had to be deployed within fresh regimes of value that amplified their status as objects worthy of museum collection and media attention. The EEF's 
founder, the novelist and popular travel-writer Amelia B. Edwards, was an adept promoter of the value of excavated artefacts, and she was equally as instrumental in the construction of the archaeological object as was Petrie's fieldwork. She wove sprawling narratives around the EEF's discoveries that were published in magazines such as Harpers Bazar and in newspaper columns for The London Times and The New York Times. For the first instalment of archaeological finds delivered from Tanis and Naukratis to the Boston Museum of Fine Arts Edwards wrote to the Editors of the Boston Daily Advertiser on December 181885 noting that:

'...it will be well to impress on the public the fact that we know exactly where everything comes from and its chronological place... with our finds, you not only know that they come from San, but you know from which house or which mound... it is hard to make people understand that very small things, of no intrinsic value, can be precious... You have some very curious and precious specimens of Egyptian glass... these look like chips and rubbish, but they testify to the level which the art of glass working had reached'.

Temporary exhibitions of the results of most seasons' excavations were displayed in locations across London further extending the products of exploration into public consciousness, including at Oxford Mansion on Oxford Street, the Society of Antiquaries Burlington House and University College London. In these spaces the complete shares of finds apportioned to the EEF by the Services des Antiquités were articulated as new coherent wholes for consumption during London's 'exhibition season' (Thornton 2015). While individually many of the finds might not attract the attention that singular works of art might, collectively the density of these displays had a monumental appeal. As The Times reported on 16 September 1886 the artefacts 'fill and more than fill, two rooms on the ground floor'. These were arguably some of the first excavations to be presented en masse, rather than distilled down to a few iconic representations or select groups of 'typical' or sensational finds.

The temporary exhibition was an intermediate space between the field and the museum, marking a significant stage in an object's transition from archaeological find to museum artefact. With most artefact groupings due to be dispersed to museums and new collections, it would be the last time that finds would acquire value through their display as an archaeological assemblage in this way. The earliest known photograph of such an exhibition (Fig. 2) captures the display of excavated finds from El-Kab, which opened with a conversazione at University College London on June 301897 (Drower 1985, 234). The crowded table-top arrangement of stone vessels, contextualised by a painting of similar objects retained in Cairo, encapsulates the characteristic style of these temporary exhibitions. The exhibition functioned as a central location in the distribution network, drawing a diverse public and professional audience for the circulation of knowledge, affirmation of object status and competition for specific pieces displayed.

At the end of each exhibition season the spectacle was disassembled and artefacts were subject to a different regime of value that once again took account of economic value, this time in the committee meetings of the EEF. Minutes and the annual reports of the EEF demonstrate the extended deliberations that evaluated the demographic spread of individual financial supporters relative to their local museums, the total sums offered by institutional subscriptions and the need to attract further funding. The 
latter meant that despite the altruistic concern regarding the need for finds to be presented to public institutions, pragmatically financial considerations always underpinned British excavation abroad (Sparks 2013). The same considerations also ensured that the distributed agency of collectors' interests across Europe, America, Australia and Asia could dictate the choice of fieldsites that might return displayworthy objects (e.g. Wainwright 1915). These networks became more formally structured in the 1890s and 1900s with the establishment of local secretaries across the UK and the US, incorporating a burgeoning number of voices across religious, educational, intellectual and social communities.

This is why multi-sited approaches are valuable for understanding archaeological collections, because museums informed practices in the field and vice versa. At the most direct, museums, such as the Royal Museum in Edinburgh sent representatives to work directly on site with Petrie's teams in order to ensure a good return (Stevenson and Libonati 2015). A second reason is that these were not uniform sets of interests since the places receiving similar sets of finds varied significantly (see table 1). As Stephanie Moser (2014) pointed out, there have been several waves of Egyptomania and multiple traditions of reception each of which requires more detailed research. The EEF's 'selection of minor antiquities', was accommodated into diverse places in which different knowledges of the past were created and affirmed, from biblical accounts and classical tales, through to contemporary fashions and politics. Multi-sited approaches help to ensure that more detailed researches into these different areas are inter-related.

Despite the popularist framing of the temporary exhibitions and media accounts, in the end many institutions and scholars were far from enthused by what they perceived as the banality of materials that were offered to them. Whereas Egyptian antiquities in places such as the British Museum had previously been self-evident 'wondrous curiosities' (Moser 2006) that were easily accommodated within displays, value was not as readily apparent in the 'selection of minor antiquities' brought back by Petrie for the EEF in 1884-85. They did not hold the same intrinsic or affective allure that the sought-after monuments, sculptures and objets d'art had. Several letters written to EEF in 1885 and 1886 contain complaints about the 'deficiency' of the antiquities received. For example, Liverpool Museum was highly critical of their share of finds (Poole 1885), leading to a 'residuum' of unallocated objects that museums 'did not care to receive' (Poole 1886). The British Museum decried the 'vast quantity of pottery and small objects' as 'worthless' (EES Archive IIIa, 47), while Charles Newton - the British Museum's Keeper of Greek and Roman Antiquities (1861-88) described a group of iron tools brought back by Petrie from Naukratis as 'ugly', and promptly disposed of them (Villing n.d.). Some reviews in the literary press were equally scathing, deriding Petrie's emphasis on banal things as 'wearisome' (Anon, The Athenaeum, 9 October 1886) and hoping that his attention to field excavation might yet reveal "really great "finds"' (Ibid).

The longer-term project of realising the latent value of such fragments was at first informed by wider nineteenth-century trends in collecting practice that stretched across a number emerging disciplines, including natural history (Raffles 2008), anthropology (Gosden and Knowles 2001), and archival studies (Spieker 2008). In all of these fields, collections were coming to be organized rationally and with respect to the contextual particularity of provenance, by which means new object identities 
could be produced through labelling and numbering (Jenkins 1994, 253). Concurrent developments in the professionalization of museum practices, such as the establishment of the UK's Museums Association in 1889, meant that curators informed and reaffirmed these procedures. Once artefacts had crossed the threshold of the museum and were accessioned into collections, further registration processes tethered them to institutional regimes that excised economic value and placed them within new sets of material relationships through further comparisons, categorisations and classifications.

For archaeology, these acts led to ways of knowing the past that could be woven into the present, as was made clear in Petrie's first excavation reports for the EEF which juxtaposed the site of the museum with that of the field:

'Here lies, then, the great value of systematic and strict excavation, in the obtaining of a scale of comparison by which to arrange and date the various objects we already possess. A specimen may be inferior to others already in a museum, and yet it will be worth more than all of them if it has its history... The aim, then, in excavating should be to obtain and preserve such specimens in particular as may serve as keys to the collections already existing'. (Petrie 1888)

Objects were made archaeological not simply by dint of being excavated, but by being marked as such, its 'context' performed by curators and journalists through tacking back and forth between objects and documents (Stevenson 2015). The practice of providing an object label or inking onto an object a date, site name orfrom 1894 onwards - context code, meant that small, 'unexceptional' fragments could be linked to larger, more significant historical edifices and established knowledge, such as locations familiar from the bible or classical sources (Gange 2013), or could be situated within institutionalised and scientifically validated typologies, like those advocated by A.H.L.F. Pitt-Rivers and Henry Flower in which the singularity of objects was not of principle interest (Bennett 1995, 41-2). Value, rather than being an essential property of things, came to be more a property distributed among things (Latour 2005).

The potential of these processes was not, however, self-evident and instructions on how to interpret archaeological finds had to be distributed with the objects themselves (Fig. 3), thereby disseminating nascent archaeological and curatorial practices to new locations. This was easier in some places than in others. While larger fine art and national museum reacted derisively to the EEF's offerings, many smaller, emerging institutions, such as the Albert Museum in Dundee, were delighted with their 'gifts of the rare and most valuable specimens of the art, architectural, fictile, and domestic of that oldest of civilisations' (Dundee Courier and Angus, 11 May 1889). These acquisitions gave such places and people the opportunity to participate in broader cultural and intellectual arenas that could be translated into prestige in local circles. In this sense, the objects themselves were arguably less important than the act of acquisition. They were a means of participating in the imperial project or, for groups such as the large number of female subscribers to the EEF, an opportunity to participate in increasingly porous, yet often still contested, intellectual arenas of the late nineteenth century.

\section{Legacies of making and remaking the unexceptional}


Problematic legacies of partage today are not only a fragmented archaeological record, but also the now widespread problem of 'orphaned' collections, things that 'have either lost curatorial support or were never curated in the first place, and to collections that were never fully analysed or reported' (Voss 2012, 145). This is a particular issue for material kept outside of museums where objects are more easily divorced from the networks that originally animated them, where their provenances may be dissolved within a generic reference to Egypt, and where excavated objects are in danger of reverting to being culturally and intellectually unexceptional. These non-museum locales account for a significant proportion of the destinations for distribution, including private schools such as Harrow and local societies like St Albans Architectural and Archaeological Society.

One such non-museum institution that received a 'selection of minor antiquities' from the EEF in 1888 was the Chautaqua Assembly, New York, a teaching camp for Sunday school teachers, that had been founded in 1874. The selection originally sent amounted to 456 items. Amongst their number were lamps, bronze figurines of gods and goddesses, coins, scarabs, statuettes, mosaics and bronze lattice-work. These had been secured for the Assembly's 'Oriental House' by the Rev. Kitteredge, regional secretary for the EEF and head of the Chautauqua Archaeological Society, whose own vision for the Assembly was to illustrate or corroborate the geography of the Middle East and to help to interpret the text of the Bible (Rieser 2003). The mass of relics was, as reported by Rudyard Kipling (Ibid.), arranged somewhat haphazardly in Chatauqua's Newton Hall. Disconnected from Petrie's own chronological emphases, the material was left to speak for itself as witness to biblical times. Newton Hall was torn down in 1929, and no record exists of what became of the majority of the items, with one exception: a statue of an Egyptian official called Menepthah, which lay forgotten, boxed-up for decades in the corner of a trolley station, until it was stumbled upon in 1979. Its association with the EEF and Flinders Petrie was re-established as one vector of value that enhanced the object's significance, as was widely reported in the media at the time (e.g. The Times, June 14 1983). Here, in the late twentieth century this 'minor antiquity' was sited in very specific regime of value in which its economic status was sensationalised over any scientific, historic or cultural worth: it garnered the highest price ever paid to that date for an antiquity at a Sotheby's sale. A similar scenario played out from the commercial sale of 'selection of minor antiquities' from Charterhouse Public School (Sotheby's 2002).

Such sales raise fundamental questions about the nature of the ownership of collections in the present, as these assemblages were initially distributed on the understanding that they were for public institutions, not for private profit. However, no contracts were signed, and documentation of any conditions of transfer has survived piecemeal, so that it is difficult to make a legal challenge to many sales. While the auctions may be legal, they are ethically problematic and their implications are far reaching not only for the fate of the objects themselves and their future accessibility, but also for the meaningfulness of archaeology as a professional endeavour. Among the many arguments against such sales (Stevenson forthcoming), , one of the most pressing is that the exceptional price tags of documented pieces continue to fuel powerful market forces that in turn threaten the security of archaeological sites where similar items are sought in order to meet a perceived demand. 
Here multi-sited approaches may play an important part in reanimating the narrative and interpretative potential of collections by fostering a better understanding of local histories within global ones. They may also make it more feasible to establish connections across sites, giving 'orphaned objects' greater meaning by integrating them within a wider whole. Such a broad-based approach to objects can be aided by online networks that allow for the dissemination of both object and archive in a space that is virtual and public, rather than private and intellectually circumscribed. It should also enable narratives to be constructed by other people who are interested in aspects other than those of archaeology or museums. To this end, the 'Artefacts of Excavation' is building an online resource to give specialists and non-specialists the tools to make their own connections between objects and histories by sharing archival information, providing guides to facilitate navigation of these documents and introducing specialist terms. In this way curators may be better able to enable new narratives, instead of controlling them. To develop such an approach is to recognise that archaeology does not just exist in the field or in the museum, but also in the many spaces in between.

\section{Acknowledgements}

This work was supported by the UK's Arts and Humanities Research Council (AHRC) under grant number AH/L004569/1. We are very grateful to John Baines for helpful comments on a previous draft.

\section{References}

Alberti, S. 2005. “Objects and the Museum.” ISIS 96 (4): 559-71.

Appadurai, A. 1986. "Introduction: Commodities and the Politics of Value." In The Social Life of Things: Commodities in Cultural Perspective, edited by A. Appadurai, 3-63. Cambridge: Cambridge University Press.

Bagh, T. 2011. Finds from W.M.F. Petrie's Excavations in Egypt in the Ny Carlsberg Glyptotek. Copenhagen: Ny Carlsberg Glyptotek.

Bennett, T. 1995. The Birth of the Museum. London and New York: Routledge.

Bennett, T. 2014. "Liberal Government and the Practical History of Anthropology." History and Anthropology 25 (2): 150-70. doi:10.1080/02757206.2014.882836

Bohrer, F. N. 2003. Orientalism and Visual Culture: Imagining Mesopotamia in Nineteenth-century Europe. Cambridge: Cambridge University Press.

Candea, M. 2013. “The Fieldsite as Device.” Journal of Cultural Economy 6 (3): 241-58.

Carruthers, W. 2014. "Egyptology, Archaeology and the Making of Revolutionary Egypt, c. 1925-1958." Unpublished PhD diss., Department of History and Philosophy of Science, University of Cambridge. 
Challis, D. 2008. From the Harpy Tomb to the Wonders of the Ephesus: British Archaeologists in the Ottoman Empire 1840-1880. London: Duckworth.

Coleman, S. and P. von Hellerman 2011. Multi-sited Ethnography: Problems and Possibilities in the Translocation of Research Methods. London: Routledge.

Colla, E. 2007. Conflicted Antiquities: Egyptology, Egyptomania, Egyptian Modernity. Durham and London: Duke University Press.

Diaz-Andreu, M. 2007. A World History of Nineteenth-century Archaeology: Nationalism, Colonialism and the Past. Oxford: Oxford University Press.

Doyon, W. 2015. "On Archaeological Labor in Modern Egypt." In Histories of Egyptology: Inter-disciplinary Measures, edited by W. Carruthers, 141-56. Routledge: London.

Drower, M. 1985. Flinders Petrie. A Life in Archaeology. London: Victor Gollancz.

Falzon, M-A. (ed.) 2009. Multi-sited Ethnography: Theory, Praxis and Locality in Contemporary Research. Aldershot: Ashgate.

Franzmeier, H. 2014. "News from Parahotep: The Small Finds From His Tomb at Sedment Re-discovered." Journal of Egyptian Archaeology 100: 151-80.

Gange, D. 2013. Dialogues with the Dead: Egyptology in British Culture and Religion. Oxford: Oxford University Press.

Gosden, C. and C. Knowles 2001. Collecting Colonialism: Material Culture and Colonial Change in Papua New Guinea. Oxford: Berg.

Gosden, C. and F. Larson 2007. Knowing Things: Exploring the Collections at the Pitt Rivers Museum 1884-1945. Oxford: Oxford University Press.

Gosden, C. and Y. Marshall 1999. "The Cultural Biography of Objects." World Archaeology 31(2): 169-78.

Hecht, G. 2012. Being Nuclear: Africans and the Global Uranium Trade. Cambridge: The MIT Press.

Hill, J. 2006. "Travelling Objects: The Wellcome Collection in Los Angeles, London and Beyond." Cultural Geographies 13: 340-66. doi: 10.1191/1474474006eu363oa

Hoock, H. 2007. "The British State and the Anglo-French Wars over Antiquities, 1798-1858." The Historical Journal 50 (1): 49-72. doi: http://dx.doi.org/10.1017/S0018246X06005917

Jenkins, D. 1994. “Object Lessons And Ethnographic Displays: Museum Exhibitions and The Making of American Anthropology." Comparative Studies in Society and History 36 (2): 242-70. doi: http://dx.doi.org/10.1017/S0010417500019046 
Kersal, M. M. 2010. "The Changing Legal Landscape For Middle Eastern Archaeology in the Colonial Era, 1800-1930." In Pioneers to the Past: American Archaeologists in the Middle East, 1880-1930, edited by G. Emberling, 85-90. Chicago: Oriental Institute of Chicago.

Kohl, P. L. and C. Fawcett 1996. Nationalism, Politics and the Practice of Archaeology. Cambridge: Cambridge University Press.

Larson, F., A. Petch and D. Zeitlyn 2007. "Social Networks and the Creation of the Pitt Rivers Museum". Journal of Material Culture 12 (3): 211-39. doi: $10.1177 / 1359183507081886$

Latour, B. 2005. Reassembling the Social: An Introduction to Actor-Network-Theory. Oxford: Oxford University Press.

Leclère, F. and J. Spencer 2014. Tell Dafana Reconsidered: The Archaeology of an Egyptian Frontier Town. London: The British Museum.

Livingstone, D.N. 2003. Putting Science in its Place: Geographies of Scientific Knowledge. Chicago: Chicago University Press.

Marcus, G.E. 1995. "Ethnography In/Of the World System: The Emergence of Multisited Ethnography." Annual Review of Anthropology 24: 95-117.

Moser, S. 2006. Wondrous Curiosities: Ancient Egypt at the British Museum. London and Chicago: University of Chicago Press.

Moser, S. 2014. "Reconstructing Ancient Worlds; Reception Studies and Ancient Egypt." Journal of Archaeological Method and Theory. doi: 10.1007/s10816-0149221-z

Petrie, W. M. F. 1883. Letter to R. S. Poole, 28 January 1883. Egypt Exploration Society Lucy Gura Archive XVI, f17.

Petrie, W. M. F. 1884. Letter to Maspero, 9 June 1884. Egypt Exploration Society Lucy Gura Archive XVI, f34.

Petrie, W. M. F. 1885. Tanis, Part I. London: Egypt Exploration Fund.

Petrie, W. M. F. 1888. Tanis, Part II. London: Egypt Exploration Fund.

Poole, R. S. 1885. Letter to the Curator of the Liverpool Museum. March 1885. Liverpool World Museum archive.

Poole, R. S. 1886. Letter to W.M. Flinders Petrie, 7 August 1886. Petrie Museum Archives.

Quibell, J. 1898. El-Kab. London: Bernard Quaritch. 
Quirke, S. 2010. Hidden Hands. Egyptian workforces in Petrie Excavation Archives 1880-1924. London: Duckworth.

Raffles, H. 2002. In Amazonia: A Natural History. Princeton: Princeton University Press.

Reid, D. 1997. Whose Pharaohs? Archaeology, Museums and Egyptian National Identity from Napoleon to World War I. London and Berkeley: University of California Press.

Rieser, A.C. 2003 The Chautauqua Moment: Protestants, Progressives and the Culture of Modern Liberalism. New York: Columbia University Press.

Robson, E, R. Horry, J.J. Taylor, S.J. Tinney, S. Zamazalová 2014. Nimrud: Materialities of Assyrian Knowledge Production. [Digital scholarly resource]. http://oracc.org/nimrud

Sayce, A. 1883. Letter to Flinders Petrie, 16 Aug. 1883. Petrie Museum Archives.

Sotheby's 2002. The Charterhouse Collection: The Property of Charterhouse, Sold by Order of the Governing Body: London, Tuesday 5 November 2002. London: Sotheby's.

Sparks, R.T. 2013. "Publicising Petrie: financing fieldwork in British Mandate Palestine (1926-1938)." Present Pasts 5(2). doi: http://dx.doi.org/10.5334/pp.56 (accessed 17 December 2014).

Spieker, S. 2008. The Big Archive: Art from Bureaucracy. Cambridge: MIT Press

Stevenson, A. 2014. "Artefacts of Excavation: The British Collection and Distribution of Egyptian Finds to Museums, 1880-1915." Journal of the History of Collections 26 (1): 89-102. DOI: $10.1093 /$ jhc/fht017

Stevenson, A. 2015. "Between the Field and the Museum: the Ongoing Project of Archaeological Context”. Egyptian and Egyptological Documents Archives Libraries 4: 109-18.

Stevenson, A. and E. Libonati 2015. "Artefacts of Excavation." Egyptian Archaeology 46, 27-9.

Stevenson, A. forthcoming. Conflict Antiquities and Conflicted Antiquities: Challenging the Sale of Legally-excavated Artefacts. Antiquity

Thornton, A. 2015. "Exhibition Season: Annual Exhibitions in London, 1880s1930s." Bulletin of the History of Archaeology 25 (2): 1-18. doi:

http://dx.doi.org/10.5334/bha.252

Trigger, B. 1996. A History of Archaeological Thought. 2nd Edition. Cambridge: Cambridge University Press. 
Villing, A. n.d. Reconstructing a $19^{\text {th }}$-century Excavation: Problems and Perspectives. http://www.britishmuseum.org/research/online_research_catalogues/ng/naukratis_gre eks_in_egypt/introduction/reconstructing_an_excavation.aspx (accessed 28 Jan 2015)

Voss, B. 2012. "Curation As Research: A Case Study in Orphaned and Underreported Archaeological Collections.” Archaeological Dialogues 19( 2): 145-69.

Wainwright, G.A. 1915. Balabish. London: Egypt Exploration Fund.

\section{Figures}

Figure 1 Foundation deposit from the pylon of the sanctuary of Amun-Ra, built under Ptolemy II Philadelphos (285-246 BC), excavated and photographed by Flinders Petrie in 1885. Courtesy of the Petrie Museum of Egyptian Archaeology, UCL, (PMAN 2680).

Figure 2 Photograph of a temporary exhibition of early third millennium BC finds from El-Kab held at University College London in 1897. Courtesy of the Petrie Museum of Egyptian Archaeology, UCL (PMAN 6550)

Figure 2 Leaflet distributed to museums circa 1900 along with their share of EEF finds. Courtesy of the Egypt Exploration Society.

\footnotetext{
1 The Egypt Exploration Fund changed its name to the Egypt Exploration Society in 1919.
} 